\title{
Fracture Related to Birth
}

National Cancer Institute

\section{Source}

National Cancer Institute. Fracture Related to Birth. NCI Thesaurus. Code C116822.

A broken bone sustained during the birthing process. 